\title{
Relationship between Bone Metabolism and Plasma Cytokine Levels in Patients at Risk of Post-Transplantation Bone Disease after Bone Marrow Transplantation
}

\author{
Wolfgang Withold ${ }^{1}$, Hans-Heinrich Wolf ${ }^{2}$, Sabine Kollbach ${ }^{1,2}$, Axel Heyll $^{2}$, Wolfgang Schneider ${ }^{2}$ and \\ Hans Reinauer ${ }^{1}$ \\ 1 Institut für Klinische Chemie und Laboratoriumsdiagnostik \\ 2 Klinik für Hämatologie, Onkologie und Klinische Immunologie \\ Heinrich-Heine-Universität Düsseldorf, Düsseldorf, Germany
}

Summary: Bone marrow transplant recipients may carry an increased risk of bone diseases, involving numerous factors that affect bone mineral metabolism. Interleukin- 6 is a potent stimulator of bone resorption in vivo. The soluble fraction of interleukin- 6 receptor is reported to trigger osteoclast formation by interleukin- 6 in vitro.

In a cross-sectional study we measured serum bone alkaline phosphatase concentrations and the urinary excretion of pyridinium cross-links in 21 patients after bone marrow transplantation, and investigated the relationship between these values and those for the plasma levels of interleukin- 6 and soluble interleukin- 6 receptor.

Following bone marrow transplantation female - but not male - patients showed higher serum bone alkaline phosphatase values than age- and sex-adjusted controls $(p<0.05)$. Both female and male patients were characterized by increased urinary excretion values of pyridinium cross-links $(p<0.05)$. In contrast to a marked increase of interleukin- 6 plasma levels $(p<0.001$ ) no significant difference in the soluble interleukin- 6 receptor levels was found between patients and apparently healthy persons $(p=0.838)$. Multiple regression analysis (taking into account different variables of the immunosuppressive regimen applied) revealed the plasma concentration of interleukin- 6 as an independent predictor of the urinary excretion of pyridinium cross-links $(p<0.05)$.

In conclusion, in patients following bone marrow transplantation, these findings indicate

(a) an increase of bone formation in female - but not in male - patients possibly reflecting primary ovarian failure and

(b) an enhancement of bone resorption possibly mediated by circulating interleukin- 6 .

\section{Introduction}

Bone marrow transplant recipients are at increased risk of bone diseases for several reasons (for review see 1.c. (1)):

(a) Sex hormone deficiency increases bone loss, especially in women following pretransplant conditioning with total body irradiation or chemotherapy;

(b) Glucocorticoids predispose to osteopenia by depressing bone formation and increasing bone resorption;

(c) Cyclosporin $\mathrm{A}$ is known to produce high bone remodelling with bone resorption exceeding bone formation and can therefore induce osteopenia when applied in immunosuppressive doses.

Reduced bone mineral density in patients following bone marrow transplantation has already been shown (2).
Following bone marrow transplantation, plasma interleukin-6 levels are regularly raised in febrile episodes (3) and associated with the induction of acute and chronic graft-versus-host reaction (4). Several studies in vitro $(5,6)$ and in vivo $(7,8,9)$ have shown that interleukin-6 is a potent stimulator of bone resorption. Interleukin- 6 exerts its activity via a cell surface receptor which consists of two components: a ligand-binding $M_{\mathrm{r}}$ 80000 glycoprotein chain (interleukin-6 receptor) and a non-ligand binding but signal-transducing $M_{\mathrm{r}} 130000$ glycoprotein chain (gp130). It has been shown that the soluble fraction of interleukin- 6 receptor which lacks transmembrane and cytoplasmic regions can also mediate the interleukin- 6 signal through gp130 (5). The soluble fraction of interleukin- 6 receptor is reported to trigger osteoclast formation by interleukin-6 in vitro (5).

In the present study bone turnover in patients following bone marrow transplantation was assessed by measuring serum mass concentrations of bone alkaline phosphatase 
(EC 3.1.3.1) (a marker of bone formation) and the urinary excretion of pyridinium cross-links (a marker of bone resorption). The resulting values were compared with the plasma levels of interleukin- 6 and the soluble fraction of its receptor.

\section{Patients and Methods}

\section{Patients}

We examined 177 blood and 44 urine samples from 21 patients after bone marrow transplantation (age: $36.1 \pm 2.0$ years) (mean $\pm \mathrm{SEM}$ ) (13 males, 8 females) (8 chronic granulocyte leukaemia, 4 acute non-lymphoblastic leukaemia, 5 'high-grade' non-Hodgkin's lymphoma, 1 Hodgkin's lymphoma, 1 acute lymphoblastic leukaemia. 1 refractory anaemia and 1 multiple myeloma). Eighteen patients received allogeneic bone marrow transplantation whereas three patients received autologous bone marrow transplantation. The mean time since transplantation was $281 \pm 16$ days (mean \pm SEM). The number of blood/urine samples obtained from each patient ranged from 3 to 29 (mean: 9).

\section{Conditioning regimens}

Seventeen patients received pretransplant conditioning with total body irradiation $(2 \mathrm{~Gy} \times 6$ or $2.5 \mathrm{~Gy} \times 4)$ and 'high-dose' cyclophosphamide $(120-180 \mathrm{mg} / \mathrm{kg} \cdot \mathrm{d})$. In four patients cyclophosphamide was given alone. Furthermore, etoposide (VP-16) $10-25 \mathrm{mg} /$ $\mathrm{kg} \cdot \mathrm{d} \times 2$ was given in 10 patients and 1,3-bis(2-chloroethyl)-1nitrosourea $5 \mathrm{mg} / \mathrm{kg} \cdot \mathrm{d}$ in 4 patients.

\section{Graft-versus-host disease prophylaxis and therapy}

To prevent graft-versus-host disease, patients undergoing allogeneic bone marrow transplantation received cyclosporin A (4 mg/ $\mathrm{kg} \cdot \mathrm{d}$ i. v. for $35 \pm 3$ days, then $12 \mathrm{mg} / \mathrm{kg} \cdot \mathrm{d}$ p. o. for $271 \pm 21$ days) (mean \pm SEM) and 'short-term' methotrexate $\left(15 \mathrm{mg} / \mathrm{m}^{2}\right.$ at day 1 and $10 \mathrm{mg} / \mathrm{m}^{2}$ at days 3 and 6 after bone marrow transplantation). Cyclosporin A concentrations in whole blood were 200-300 $\mu \mathrm{g} / \mathrm{l}$ in the first six months after bone marrow transplantation. Five of the patients received prednisolone $1-1.5 \mathrm{mg} / \mathrm{kg} \cdot \mathrm{d}$ p. 0 .

All female patients following bone marrow transplantation had clinical and biochemical evidence of primary ovarian failure. None of the patients had clinical or biochemical signs of disturbed vitamin D or phosphate metabolism. Moreover, none of the patients had had any bone disease before transplantation [bone density measurements (using dual-energy $\mathrm{X}$-ray absorptiometry) performed before transplantation yielded values within the reference range both at the lumbar spines as well as at the femoral neck (as compared with sex- and age-adjusted controls)].

\section{Methods}

Bone alkaline phosphatase mass concentration in serum was determined by an immunoradiometric assay (Tandem ${ }^{\circledR}-\mathrm{R}$ Ostase ${ }^{\mathrm{TM}} ; \mathrm{Hy}-$ britech Inc., San Diego, CA [U.S. A.]; no. 3040 BE) employing two monoclonal antibodies against two different epitopes of the bone alkaline phosphatase molecule. A calibration curve was constructed by linear interpolation between the plotted analytical results. The following reference intervals (mean $\pm 2 \times \mathrm{SD}$ ) for bone alkaline phosphatase concentrations in serum were established in apparently healthy persons: (1) $3.2-15.8 \mu \mathrm{g} / \mathrm{l}$ (males, $\mathrm{n}=38$ ) (2) $2.3-12.2 \mu \mathrm{g} / \mathrm{l}$ (females, $\mathrm{n}=47$ ). Age-range was $27-51$ years (males) and 19-48 years (females). Bone alkaline phosphatase values were higher in males than in females $(p<0.0001)$.

The urinary excretion of pyridinium cross-links was determined by a competitive enzyme immunoassay (Collagen Crosslinks ${ }^{\mathrm{TM}} \mathrm{Kit}$; Metra Biosystems Inc.; Palo Alto, CA [U. S. A.]) employing a polyclonal antibody against pyridinoline which shows $100 \%$ cross-reactivity with deoxypyridinoline. A curve was constructed employing a 4-parameter curve fitting equation. The following reference interval (mean $\pm 2 \times \mathrm{SD}$ ) for the urinary excretion of pyridinium cross-links in second morning urine samples was established in apparently healthy persons (the samples were obtained between 8.00 and 10.00 a. m.): pyridinoline equivalents, $12-73 \mu \mathrm{mol} / \mathrm{mol}$ creatinine $(n=75 ; 33$ males and 42 females; age-range: $20-56$ years). There was no dependence of reference values upon sex.

Plasma levels of interleukin-6 were determined with an enzyme immunoassay (Quantikine ${ }^{\mathrm{TM}}$ HS Human. LL-6 Immunoassay; R \& D Systems; Minneapolis, MN [U. S. A.]). The upper reference limit (mean $+2 \times \mathrm{SD} ; \mathrm{n}=23 ; 17$ males and 6 females) was $2.4 \mathrm{ng} / 1$.

The soluble plasma fraction of interleukin- 6 receptor was determined with an enzyme immunoassay (Quantikine ${ }^{\mathrm{TM}}$ Human IL-6 sR Immunoassay; R \& D Systems; Minneapolis, MN [U.S. A.]). The reference interval (mean $\pm 2 \times \mathrm{SD} ; \mathrm{n}=23 ; 17$ males and 6 females) was $9.7-67.4 \mu \mathrm{g} / \mathrm{l}$.

The potassium salt of ethylenediaminetetraacetic acid was used as anticoagulant in the latter two tests.

\section{Statistical analysis}

The statistical methods employed included the U-test according to Wilcoxon, Mann \& Whitney (two-tailed) for unpaired samples and linear correlation coefficients (10). Multiple regression analysis was performed with SPSS/PC+ V2.0 employing the procedure REGRESSION with a 'stepwise' selection of the independent variables.

\section{Results}

Comparison of mean values obtained from each patient revealed that following bone marrow transplantation, female - but not male - patients showed higher serum bone alkaline phosphatase values than age- and sex-adjusted controls $(p<0.05)$. After bone marrow transplantation both female and male patients showed a higher urinary excretion of pyridinium cross-links than apparently healthy persons $(p<0.05)$. There was a lack of correlation between serum bone alkaline phosphatase values and the urinary excretion of pyridinium crosslinks $(p=0.562)$ (tab. 1 and fig. $1 \mathrm{a}, \mathrm{b})$. No correlation was observed between the values of these two biochemi-

Tab. 1 Z score analysis of biochemical markers of bone metabolism and plasma cytokine levels in patients following bone marrow transplantation.

\begin{tabular}{lll}
\hline Analyte & Sex & Z score \\
\hline Serum bone alkaline phosphatase & Females & $+2.97^{*}$ \\
& Males & +0.45 \\
Urinary excretion of & Females & $+1.54^{*}$ \\
pyridinium cross-links & Males & $+2.06^{*}$ \\
Interleukin-6 & - & $+4.87^{* * *}$ \\
Soluble fraction of & - & -0.03 \\
interleukin-6 receptor & & \\
\hline
\end{tabular}

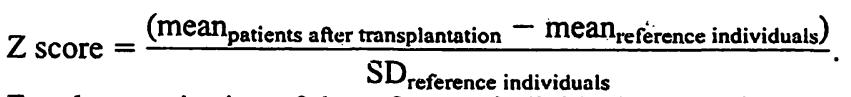

For characterisation of the reference individuals see under Patients and Methods. The age of the reference individuals did not significantly differ from that of the patients $(p>0.05)$.

$* \mathrm{p}<0.05$

$* * * \mathrm{p}<0.001$ 
cal markers of bone metabolism (measured after transplantation) and bone mineral density (at lumbar spines or femoral neck) (obtained before transplantation) $(p>0.05)$.

Following bone marrow transplantation there was a marked increase of interleukin-6 plasma levels $(p<0.001)$ but no significant difference in the soluble plasma fraction of its receptor between patients and apparently healthy persons $(p=0.838)$. Both in apparently healthy persons as well as in patients following bone marrow transplantation there was a lack of correlation between plasma interleukin- 6 concentrations and the soluble plasma fraction of its receptor $(p>0.5)$ (tab. 1 and fig. 1c, d).

There was no correlation between the values of pyridinium cross-links excretion, plasma interleukin- 6 and plasma soluble interleukin- 6 receptor levels on the one hand and time after transplantation on the other $(p>0.05)$, whereas a significant increase of serum bone alkaline phosphatase was observed within the first year after transplantation $(p<0.01)$.
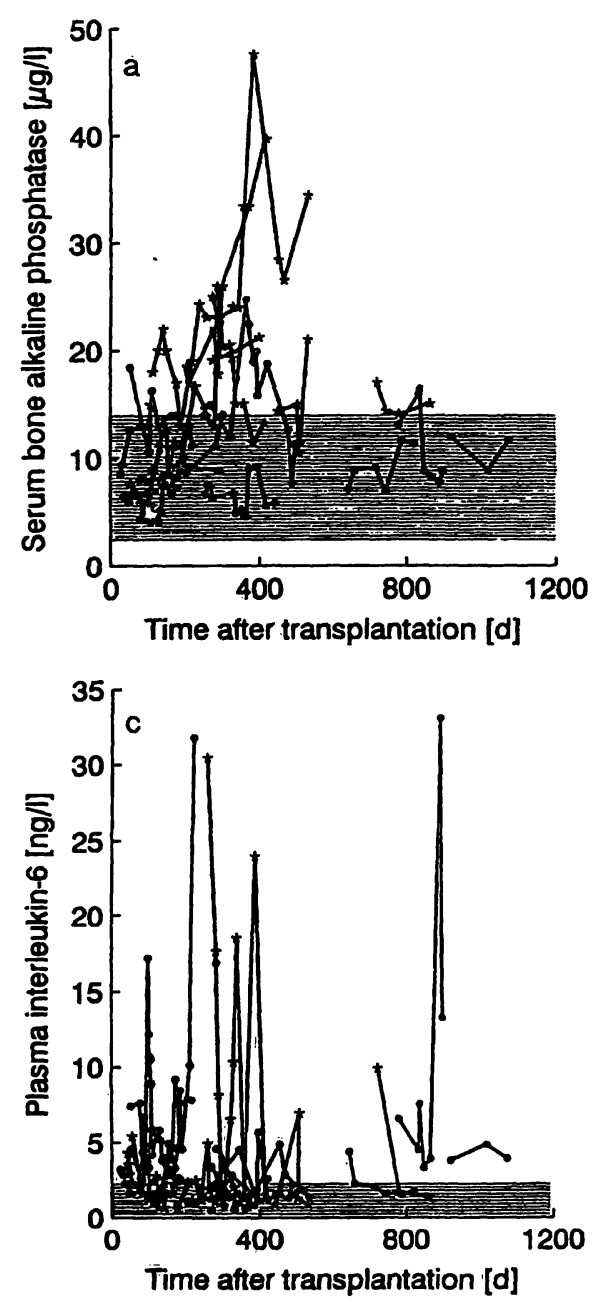

Fig. 1 Relationship between biochemical marker values of bone metabolism/plasma cytokine levels and time after transplantation in patients following bone marrow transplantation.

The shaded areas denote the reference interval (mean $\pm 2 \times$ SD)

(for characterisation of the reference individuals see Patients and Methods). For bone alkaline phosphatase concentrations the depen-
Bivariate analysis showed a significant correlation between the urinary excretion of pyridinium cross-links and plasma interleukin- 6 concentrations (tab. 2). To assess other possible influences upon the urinary excretion of pyridinium cross-links, the relative effects of the following independent variables were determined by multiple regression analysis:

Tab. 2 Correlation coefficients between biochemical markers of bone metabolism and plasma cytokine levels in patients after bone marrow transplantation.

\begin{tabular}{ll}
\hline Analytes & $\begin{array}{l}\text { Correlation } \\
\text { coefficients }\end{array}$ \\
\hline $\begin{array}{l}\text { Serum bone alkaline phosphatase vs } \\
\text { plasma interleukin-6 concentrations }\end{array}$ & $\mathrm{r}=-0.124$ \\
Serum bone alkaline phosphatase vs & $\mathrm{p}>0.05$ \\
plasma interleukin-6 receptor concentration & $\mathrm{r}=-0.088$ \\
Urinary excretion of pyridinium cross-links vs & $\mathrm{p}>0.05$ \\
plasma interleukin-6 concentration & $\mathrm{r}=+0.389$ \\
Urinary excretion of pyridinium cross-links vs & $\mathrm{p}=0.012$ \\
plasma interleukin-6 receptor concentration & $\mathrm{r}=+0.285$ \\
\hline
\end{tabular}
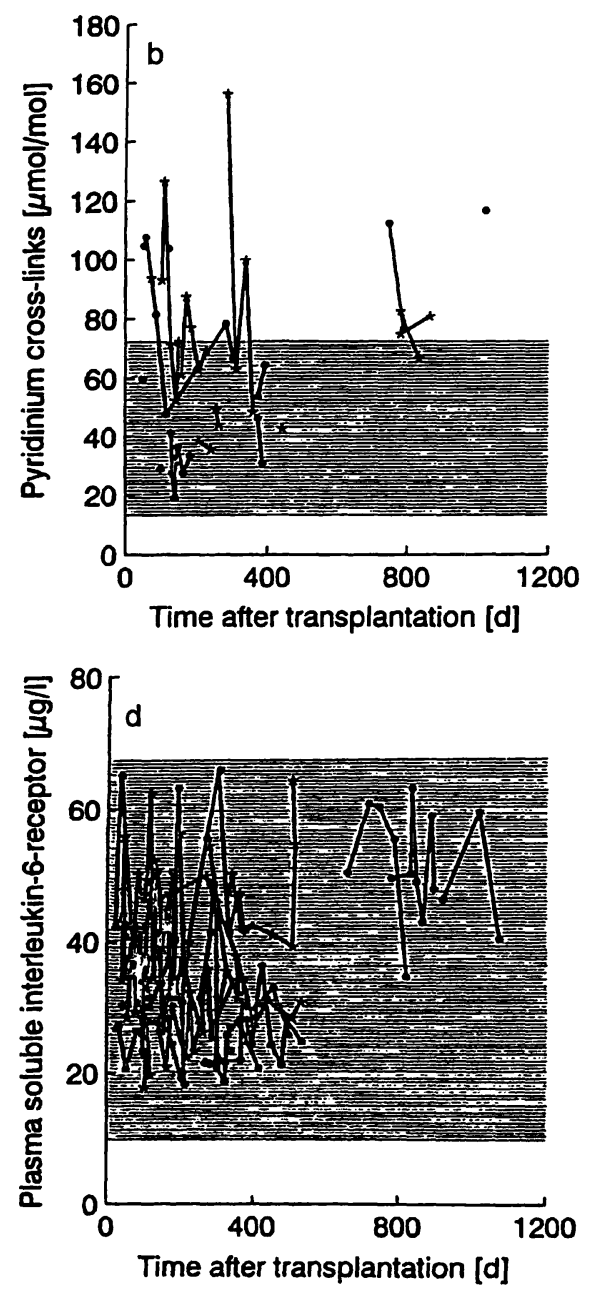

dence of the reference values upon sex was not considered. Data pairs belonging to the same patients are connected by lines. Sanples obtained from female patients are designated by asterisks, those from male patients by dots.

The pyridinium cross links content is referred to creatinine. 
(a) plasma interleukin-6 concentration;

(b) cumulative dose of cyclosporin $\mathrm{A}$ and duration of cyclosporin A therapy;

(c) cumulative dose of prednisolone, dose of prednisolone at the day of sample collection and duration of prednisolone therapy.

The plasma concentration of interleukin- 6 was the only independent predictor of the urinary excretion of pyridinium cross-links $(p<0.05)$ (tab. 3 ).

\section{Discussion}

In female, but not in male patients, there was a significant increase in the serum bone alkaline phosphatase values as compared with age- and sex-matched controls. This may be explained by the influence of primary ovarian failure following total body irradiation, whereas in men only a moderate elevation of gonadotropins and testosterone within the reference interval were observed (2, 11). Cyclosporin A may enhance the deleterious effect of oestrogen deficiency, since in oophorectomised rats bone mass loss is accelerated by the application of cyclosporin A (12).

Carlson et al. (13) found a depression of bone formation within the first three months following bone marrow transplantation, which is probably due to

(a) an inhibitory effect of glucocorticosteroids upon bone formation,

(b) damage of osteoprogenitor cells by the myeloablative therapy and

(c) inhibition of osteoblast function by locally secreted cytokines. However, the follow-up period of this study was only 3 months after bone marrow transplantation, whereas in the present communication the mean time since transplantation was 281 days.

Reduced bone mineral density is a common finding in patients following liver, cardiac and bone marrow transplantation $(2,14,15,16)$. This is in concordance with our findings of increased values of both bone formation

Tab. 3 Independent predictor variables for the urinary excretion of pyridinium cross-links in patients after bone marrow transplantation.

\begin{tabular}{llll}
\hline $\begin{array}{l}\text { Predictor } \\
\text { variable } \\
\text { in model }\end{array}$ & $\begin{array}{l}\text { Regression } \\
\text { coefficient (B) } \\
\pm \text { S. E. }\end{array}$ & $\begin{array}{l}\text { Significance } \\
\text { of variable }\end{array}$ & $\begin{array}{l}\text { Multiple } \\
\text { correlation } \\
\text { coefficient } \\
(\mathrm{r})\end{array}$ \\
\hline $\begin{array}{l}\text { Plasma } \\
\text { interleukin-6 } \\
\text { concentration }\end{array}$ & $3.39 \pm 1.16$ & 0.006 & 0.508 \\
\hline
\end{tabular}

a Significance refers to the $\mathrm{p}$ value at final step. and bone resorption, indicating increased bone turnover. Interestingly no correlation was found between bone alkaline phosphatase mass concentrations in serum and the urinary excretion of pyridinium cross-links. This is in contrast to previous findings of our group, as well as others, in patients with primary (17) or secondary (18) hyperparathyroidism and bone metástases $(19,20)$, indicating that in patients after bone marrow transplantation different influencing factors may affect bone formation and resorption, respectively.

A multivariate statistical approach revealed the plasma concentration of interleukin- 6 as an independent predictor of the urinary excretion values of pyridinium crosslinks, whereas there is no augmenting effect of the soluble interleukin- 6 receptor upon bone metabolism in patients undergoing bone marrow transplantation. In contrast, Tamura et al. (5) found that only simultaneous treatment with interleukin- 6 and soluble interleukin- 6 receptor induces formation of osteoclast-like cells in vitro.

Several authors have observed that interleukin- 6 enhances bone resorption in vivo:

(a) Inoculation of nude mice with Chinese hamster ovarian cells, which have been transfected with the murine interleukin-6 gene, induces hypercalcaemia (7);

(b) Neutralising antibodies directed against interleukin6 reverse hypercalcaemia associated with a human carcinoma cell line transplanted in nude mice (8);

(c) In oophorectomised rats, increased osteoclast development is mediated by interleukin-6 (9).

Recently, Khosla et al. (21) found that postmenopausal women did not show higher plasma interleukin-6 levels as compared with premenopausal women. However, the interleukin-1 $\alpha /$ interleukin-1 receptor antagonist concentration ratio was significantly increased in postmenopausal women (21), suggesting a possible effect of cytokines upon bone metabolism in postmenopausal women.

In conclusion, our findings suggest two variables possibly acting on bone metabolism in patients after bone marrow transplantation:

(1) Increase of bone formation in female - but not male - patients, possibly reflecting primary ovarian failure;

(2) Enhancement of bone resorption possibly mediated by circulating interleukin- 6 . However, it is admitted that numerous factors can affect bone mineral metabolism in patients undergoing organ transplantation (e.g., longterm parenteral nutrition, disturbances of vitamin $\mathrm{D}$ and phosphate metabolism, action of drugs) which may be difficult to differentiate in cross-sectionally designed clinical studies (1). 


\section{References}

1. Katz IA, Epstein S. Posttransplantation bone disease. J Bone Miner Res 1992; 7:123-6.

2. Kelly PJ, Atkinson K, Ward RL, Sambrock PN, Biggs JC, Eisman JA. Reduced bone mineral density in men and women with allogeneic bone marrow transplantation. Transplantation 1990; 50:881-3.

3. Chasty RC, Lamb WR, Gallati H, Roberts TE, Brenchley PE, Yin.JA. Serum cytokine levels in patients undergoing bone marrow transplantation. Bone Marrow Transplant 1993; $12: 331-6$.

4. Imamura $M$, Hashino $S$, Kobayashi $H$, Kubayashi $S$, Hirano $S$, Minagawa $T$, et al. Serum cytokine levels in bone marrow transplantation: synergistic interaction of interleukin-6, interferon- $\gamma$, and tumor necrosis factor- $\alpha$ in graft-versus-host disease. Bone Marrow Transplant 1994; 13:745-51.

5. Tamura T, Udagawa N, Takahashi N, Miyaura C, Tanaka S, Yamada $Y$, et al. Soluble interleukin-6 receptor triggers osteoclast formation by interleukin-6. Proc Natl Acad Sci USA 1993; 90:11924-8.

6. Lorenzo JA. The role of cytokines in the regulation of local bone resorption [review]. Crit Rev Immunol 1991; 11:195213.

7. Black K, Garrett IR, Mundy GR. Chinese hamster ovarian cells transfected with the murine interleukin- 6 gene cause hypercalcaemia as well as cachexia, leukocytosis and thrombocytosis in tumor-bearing nude mice. Endocrinology 1991; 128:2657-9.

8. Yoneda T, Nakai M, Moriyama K, Scott L, Ida N, Kunitomo $T$, et al. Neutralizing antibodies to human interleukin- 6 reverse hypercalcemia associated with a human squamous carcinoma. Cancer Research 1993; 53:737-40.

9. Jilka RL, Hangoe G, Girasole G, Passeri G, Williams DC, Abrams JS, et al. Increased osteoclast development after estrogen loss: mediation by interleukin-6. Science 1992; 257:88-91.

10. Sachs L. Statistische Methoden: Planung und Auswertung. 6th ed. Berlin, Heidelberg, New York, London, Paris, Tokyo: Springer, 1988.

11. Benker $G$, Schäfer U, Hermanns U, Mahmoud MK, Olbricht $\mathrm{T}$, Schulte HM, et al. Allogeneic bone marrow transplantation in adults: endocrine sequelae after $1-6$ years. Acta Endocrinol (Copenh) 1989; 120:37-42.

12. Joffe I, Katz I, Jacobs T, Stein B, Takizawa M, Liu C, et al. $17 \beta$-estradiol prevents osteopenia in the oophorectomized rat treated with cyclosporin A. Endocrinology 1992; 130:157886.

13. Carlson K, Simonsson B, Ljunghall S. Acute effects of highdose chemotherapy followed by bone marrow transplantation on serum markers of bone metabolism. Calcif Tissue Int 1994; 55:408-11

14. Arnold JC, Hauser D, Ziegler R, Kommerell B, Otto G, Theilmann $\mathrm{L}$, et al. Bone disease after liver transplantation. Transplant Proc 1992; 24:2709-10.

15. Eastell R, Dickson ER, Hodgson SF, Wiesner RH, Porayko MK, Wahner HW. Rates of vertebral bone loss before and after liver transplantation in women with primary biliary cirrhosis. Hepatology 1991; 14:296-300.

16. Shane E, Rivas MC, Silverberg SJ, Kim TS, Staron RB, Bilezikian JP. Osteoporosis after cardiac transplantation. Am J Med 1993; 94:257-64.

17. Seibel MJ, Gartenberg F, Silverberg SJ, Ratcliffe A, Robins SP, Bilezikian JP. Urinary hydroxypyridinium cross-links of collagen in primary hyperparathyroidism. J Clin Endocrinol Metab 1992; 74:481-6.

18. Withold W, Degenhardt S, Heins M, Grabensee B, Reinauer $H$. Monitoring of bone resorption after renal transplantation by measuring the urinary excretion of pyridinium cross-links. Eur J Clin Chem Clin Biochem 1995; 33:15-21.

19. Paterson CR, Robins SP, Horobin JM, Preece PE, Cuschieri A. Pyridinium crosslinks as markers of bone resorption in patients with breast cancer. Br J Cancer 1991; 64:884-6.

20. Withold W, Khakzad H, Georgescu G, Vosberg H, MuellerGaertner HW, Reinauer H. Efficacy of simultaneous determination of bone alkaline phosphatase mass concentration in serum and urinary excretion of pyridinium cross-links for detection of bone metastases. Clin Biochem 1995; 28:479-85.

21. Khosla S, Peterson JM, Egan K, Jones JD, Riggs BL. Circulating cytokine levels in osteoporotic and normal women. $\mathrm{J}$ Clin Endocrinol Metab 1994; 79:707-11.

\section{Received October 17, 1995/January 3, 1996}

Corresponding author: Dr.med. Wolfgang Withold, Institute for Clinical Chemistry and Laboratory Diagnostics, Heinrich-HeineUniversity of Düsseldorf, Moorenstraße 5, D-40225 Düsseldorf, Germany 
